\title{
RISK ASSESSMENT OF MOBILE PHONES USING FAILURE MODE AND EFFECTS ANALYSIS
}

\author{
Ana Bašić, \\ Predrag Popović
}

Singidunum University,

32 Danijelova Street, Belgrade, Serbia

\section{Correspondence:}

Ana Bašić

e-mail:

ana.basic@ratel.rs

\begin{abstract}
:
The use of mobile phones implies the existence of a risk to users of this kind of equipment. An additional problem is that for the radio equipment there is still no general standard which defines principles for the design of this type of equipment with the emphasis on assessment and risk reduction. Failure in hardware and software in mobile phones is one of possible risks. The effects of failure cause problems in mobile phones, customer dissatisfaction, cost ineffectiveness, poor marketing for manufacturers, etc. The causes and effects of failure analysis will help the user and manufacturer to understand the system more effectively and also to avoid the failures as much as possible. This paper presents the failure mode and effect analysis of the mobile phone. The aim of the research is to analyze the whole mobile phone system with its components and their potential failure modes. Based on the proposed analysis, the paper shows calculation of Risk Priority Numbers for various mobile phone components. The results of this research represent attachment to the general methodology of assessment and risk reduction of mobile phones.
\end{abstract}

Key words:

mobile phone, risk assessment, Failure Mode and Effect Analysis

(FMEA), Risk Priority Number (RPN).

\section{INTRODUCTION}

Advances in science and technology have enabled people the access to many means that facilitate their lives. In addition to mobile phones, lap tops, payment cards, navigation devices and Internet, there are many more useful products of the present day scientific-technological revolution. However, many of the technical products which make the everyday life easier, more interesting and economical have got negative consequences to health and safety of users, as well as to the environment. Unfortunately, these negative effects are very often put into the rear plan with respect to the usefulness, usability and technological power of new technical products.

Risk assessment and management in technical systems constitute very important economic and general social issue. Risk is an economic category in the sense that it has its price, its market and its buyers. Technical systems risk management is possible only if there is knowledge of the phenomena by which it is managed, as well as of the management methods.

If risk is expressed as the product of an unwanted effect occurrence probability and consequences of that event, the risk is then represented as 
the product of one real and one imaginary component. Nevertheless, practice has shown that this definition is very practical and that it enables risk management to be executed in adequate ways. Consequences of an unwanted event can relate not only to economic and financial losses, but also to health issues and the environment, to market prestige and competition, to social and political factors, customer dissatisfaction, etc. This means that consequences of unwanted events can be expressed in different ways, depending on the system analyzed and the nature of the damage. Assessment of unwanted event consequences is very simple if financial losses are assessed, while it is much more difficult in cases of unwanted events' effects on health and environment, i.e. when it is difficult to measure the consequences. When considering probability of an unwanted event occurrence, the risk there is related to technical systems' reliability performances. In such cases, reliability of a technical system represents capability of the system to operate without failure, under the same conditions and in the given period of time.

The conformity assessment procedure for technical products implies that safety requests have been integrated into the design project. In the course of designing technical products, risk levels are analyzed and quantified with the goal of determining the necessary safety systems. The New Approach Directives, as well as some harmonized standards, explicitly state the risk assessment procedure. When risk assessment isn't stated in the Directive, it may be required by the standard related to that Directive (Đapić et al., 2012).

In the new Radio Equipment Directive 2014/53/EU, which comes into force in June 2016, it is noticeable that it covers the activities which deal with risk assessment of this type of equipment. However, there still is not a general standard which would define the principles for designing such equipment pointing out risk assessment and risk reduction (Bašić and Popović, 2014). The ADCO R\&TTE Group has worked intensively on the project of devising the radio equipment risk assessment procedure for several years now.

The object of this research is application of technical systems' failure analysis in the context of radio equipment risk assessment. The Failure Mode and Effects Analysis have been performed on the mobile phone as the typical representative of radio equipment. Special attention has been paid to analyzing failures that may occur in mobile phone hardware, as well as in software. Ten most frequent failure modes have been identified for which the complete FMEA has been performed and the Risk Priority Number (RPN) value calculated.
The object of research was approached by applying the basic risk management principles. The results of this paper, achieved by simultaneous implementation of engineering principles and basic risk management principles, represent a contribution to designing efficient technical systems and at the same time they represent a contribution to the project of devising the radio equipment risk assessment methodology. At the end of the paper, the use of FMEA method is justified and the advantages and shortcoming of its use are stated. Problems encountered in using the FMEA method are pointed out and the obtained results are explained in detail and guidelines are added for their further implementation.

\section{RADIO EQUIPMENT RISK ASSESSMENT}

The European Commission has initiated development of several generic harmonized standards to enable systematic approach and provide guidelines for identifying hazards, risk assessment of these hazards and acceptability assessment of the selected safety measures. At the moment, there are numerous standards for risk assessment and reduction in technical products, defined in the New Approach Directives. The risk assessment and reduction standards are very well developed in the areas of machines (Directive MD 2006/42/EC), lifts (Directive 2014/33/ EU) as well as in the equipment and safety systems used in potentially explosive atmospheres (Directive ATEX 2014/34/EU).

In recent years an extensive research has been ongoing related to the development and implementation of radio equipment risk assessment methodology. In these research bases for adequate methodology development are the standards for technical products' risk assessment defined in the New Approach Directives. Potential hazards that may occur in radio equipment use should be regarded through several aspects. Only when the research issues are approached from multiple sides it is possible to obtain complete data.

The constant issue is whether there are risks in radio equipment usage, and what level they are, primarily in the use of mobile phones. There are many different opinions based on numerous studies and research works. The risks that exist in mobile phone use are not just the risks related to the device's failure effects, electromagnetic radiation effects, occurrence of interference, etc. The risks of mobile phone use should be considered from the health, ethical, social and environmental stand point (Bašić and Popović, 2015). 
Developing the methodology for radio equipment risk assessment is an extremely complex issue. This issue should not be approached only from the engineering point of view. The desirable approach is the one from the management point of view as it will point out not only to the engineering but to other issues as well, giving proposals for resolving these issues. Within this paper, the issue of radio equipment, i.e. mobile phone risk assessment, has been approached by way of one of the basic tools used in the engineering management. Different failure modes and effects have been analyzed by FMEA in the context of radio equipment risk assessment.

Occurrence of any kind of failure brings about problems in mobile phone regular operation which simultaneously render very bad marketing for manufacturer of the device. FMEA analysis results can be of significant assistance to both manufacturers and users of the equipment, enabling them to gain better knowledge of the system's operation and to avoid failure occurrence whenever it is possible.

Square Trade Company has conducted a very interesting research on smart phones' failure rates. The research lasted for 12 months and covered more than 50 thousand mobile devices from different manufacturers. Figure 1 depicts the results achieved by Square Trade relating to failure rates in the period of 12 months in different types of smart devices.

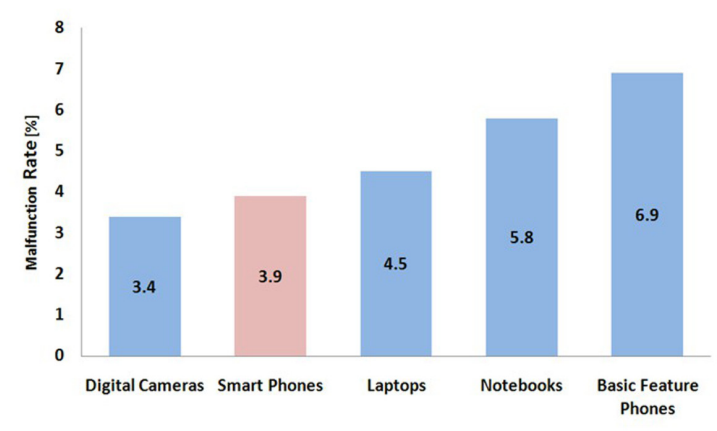

Figure 1. Malfunction rate in various types of radio equipment as per (Square Trade Research brief, 2010).

Manufacturing of smart phones commenced in 2006. In ten years' time of their manufacturing, reliability of these devices has improved significantly. The results of this analysis depicted in Figure 1 shows that smart phones take the second place with the failure rate of $3.9 \%$, i.e. it shows that devices such as lap tops, notebooks and basic feature phones are less reliable in respect to smart phones (Square Trade Research brief, 2010).
If the analysis of smart phone failures is simplified, it is possible to define two basic types. To put it more precisely, failures can occur due to an accident or due to the mobile phone hardware or software failure/malfunction. According to the data acquired by Square Trade, two most frequent accidents leading to mobile phone malfunction/failure are falling and soaking of the device. Fig. 2 depicts very interesting results of the ratio of failure rate due to malfunction and failure rate due to accidents in mobile phones of various manufacturers. The results of the analysis show that failure rate due to software or hardware malfunction is less compared to failure/malfunction rate due to accident occurring in mobile phone usage (Square Trade Research brief, 2010).

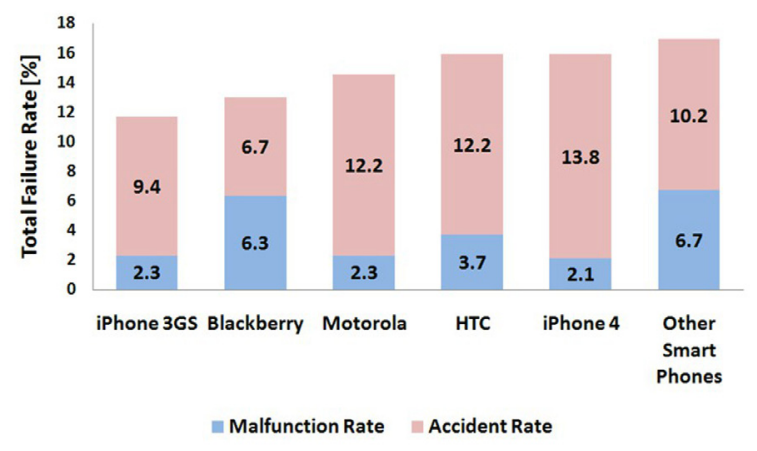

Figure 2. Overall Failure Rate due to accident and malfunction as per (Square Trade Research brief, 2010).

\section{FAILURE MODE AND EFFECT ANALYSIS}

\section{General characteristics of the FMEA method}

FMEA method is one of the basic system tools used in the engineering management. This method is widely applied and can be used for both equipment and objects, as well as for the manufacturing operations analysis and their effects on the product or on the entire process. FMEA can be used in all phases of the system's life, from the initial system specification, system implementation and further to its management and maintenance. The use of FMEA in analyzing technical systems failures enables identification of all potential failure modes of the technical system elements and failure occurrence causes, as well as for assessing failure effects.

The basic advantages in applying the FMEA method are:

- Early identification of errors in the technical system, thus avoiding subsequent expensive modifications of the system; 
- Identification of failures which have unacceptable effects on the system's operation and/or which can severely jeopardize users' safety;

- The possibility to determine whether there is the need for increasing system reliability (redundancy, components selection, etc.);

- The possibility to form a logical model for assessing probability of irregular working conditions occurrence with the aim of preparing the technical system for the criticality analysis;

- Efficient detection of the problems related to technical system safety, as well as to the system conformity with normative requirements;

- Assistance in determining key issues towards which quality control and manufacturing process control should be directed;

- Assistance in determining the strategy of technical system preventive maintenance;

- Assistance in isolating failures and planning of alternative modes of operation and in planning the system configuration improvements;

- Assistance to designers in understanding the factors that affect technical system reliability.

\section{The procedure for FMEA method realization}

The FMEA method represents the system analysis and logical technique which enables performing the system reliability assessment on the basis of consideration of potential, individual failures. The objective of FMEA method application is to define the answers to the following questions:

- What are the possible causes of identified system failures?

- What are the effects of identified failures at the level of elements/subsystems?

- What are the most efficient means for detection of failures?

- What is the failure frequency in the observed system?

Figure 3 is a graphic depiction of the basic FMEA method phases.

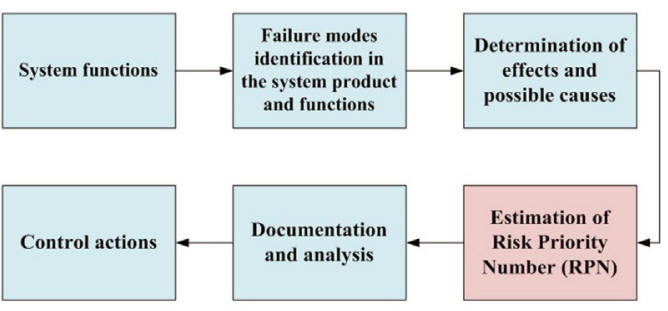

Figure 3. The basic FMEA method phases
The procedure of implementing the FMEA method always begins with identifying the purpose and all functions of the observed system. It is necessary to gather basic data on the system, such as: structure and limits of the system, the system level which is analyzed, description of functioning of all system parts, environment conditions, etc.

The next step is identification of all possible failure modes. It is very important to collect as many data on the system failures, on failure causes and effects, ways of failure detection, procedures for failure compensation, classification of criticality and probability of occurrence. It has been proved in practice that implementing of the brainstorming method enables very good results in identifying failure modes.

The next phase encompasses determining causes and effects of the defined failure modes. In determining the failure effect severity (Severity), failure occurrence probability (Occurrence) and estimation of the possibility to detect failure before it jeopardizes operation of the system (Detection), the values are used as given in Table 1, Table 2 and Table 3, respectively (Marques, 2010).

\begin{tabular}{|c|c|c|}
\hline Index & Severity & Criteria \\
\hline 1 & Very low & $\begin{array}{l}\text { Failure occurrence almost unnoticed by the } \\
\text { client }\end{array}$ \\
\hline $\begin{array}{l}2 \\
3\end{array}$ & Low & $\begin{array}{l}\text { Slight decline in the quality of the observed } \\
\text { system performances and occurrence of mar- } \\
\text { ginal customer's dissatisfaction }\end{array}$ \\
\hline $\begin{array}{l}4 \\
5 \\
6\end{array}$ & Moderate & $\begin{array}{l}\text { Significant decline of the system performanc- } \\
\text { es quality and dissatisfaction of the customer }\end{array}$ \\
\hline $\begin{array}{l}7 \\
8\end{array}$ & High & $\begin{array}{l}\text { The system stops working; high customer } \\
\text { dissatisfaction }\end{array}$ \\
\hline $\begin{array}{c}9 \\
10\end{array}$ & Very high & $\begin{array}{l}\text { The system stops working; very high customer } \\
\text { dissatisfaction; safety problems }\end{array}$ \\
\hline
\end{tabular}

Table 1. Determining failure effect severity (Severity)

\begin{tabular}{cll}
\hline Index & Occurrence & Proportion \\
\hline 1 & Very low & $1: 1000000$ \\
\hline 2 & \multirow{2}{*}{ Low } & $1: 20000$ \\
3 & & $1: 4000$ \\
\hline 4 & \multirow{2}{*}{ Moderate } & $1: 1000$ \\
5 & & $1: 400$ \\
6 & \multirow{2}{*}{ High } & $1: 80$ \\
\hline 7 & & $1: 20$ \\
8 & \multirow{2}{*}{ Very high } & $1: 8$ \\
9 & & $1: 2$ \\
\hline
\end{tabular}

Table 2. Determining failure occurrence probability (Occurrence) 


\begin{tabular}{crl}
\hline Index & Detection & \multicolumn{1}{c}{ Criteria } \\
\hline 1 & Very high & $\begin{array}{l}\text { Failure will be detected before it jeopardizes } \\
\text { system operation/ the customer }\end{array}$ \\
\hline 3 & High & $\begin{array}{l}\text { There is high probability for the failure to be } \\
\text { detected before it jeopardizes system opera- } \\
\text { tion/ the customer }\end{array}$ \\
\hline 5 & Moderate & $\begin{array}{l}\text { Failure will probably be detected before it } \\
\text { jeopardizes system operation/ the customer }\end{array}$ \\
\hline 7 & Low & $\begin{array}{l}\text { Failure will probably not be detected before it } \\
\text { jeopardizes system operation/ the customer }\end{array}$ \\
\hline 8 & Very low & $\begin{array}{l}\text { Failure will not be detected on time; regular } \\
\text { system operation and customer's safety are } \\
\text { jeopardized }\end{array}$ \\
\hline 10 & &
\end{tabular}

Table 3. Assessment of the possibility to detect failure before it jeopardises system operation/the user (Detection)

The next step in the procedure of FMEA implementation is calculation of the RPN value, which represents failure criticality degree assessment and also risk priority assessment. All failures in the system can be ranked with respect to RPN, where high RPN value denotes high priority in problem solving. The RPN value is calculated by the next equation:

$R P N=S \times O \times D$

- $S$ (Severity) - failure effect severity, i.e. assessment of how much the detected effect affects and jeopardizes system operation/the customer;

- $\mathrm{O}$ (Occurrence) - failure occurrence probability;

- $\mathrm{D}$ (Detection) - estimation of possibility for the failure to be detected before it jeopardizes system operation and/or the user.

In the obtained RPN value is less than 50 , the failure criticality degree is low. For the RPN values from 50 to 100 , the failure criticality degree is considered to be moderate, or from 100 to 200 , the failure criticality degree is considered to be high. For all RPN values over 200, the failure criticality degree is considered to be very high, i.e. these are the failures which have priority in problem solving. The last step in the procedure of FMEA application is documenting of the implemented procedure and taking of actions with the aim of risk reduction for the identified failure modes.

\section{Application of FMEA method to technical systems hardware and software}

Application of the FMEA method with the goal of failure analysis implies implementing of the method to both hardware and software of the technical system. In cases when there is a reduced rate of failure occurrence in the system, reliability in the system is increased. However, there is a significant difference between hardware failure rate and software failure rate, which is depicted in Figure 4 by the reliability curves (Vijayalakshmi, 2014).

If observing the technical system's hardware reliability curve, it is evident that after manufacturing of a certain component, the number of failures becomes high.
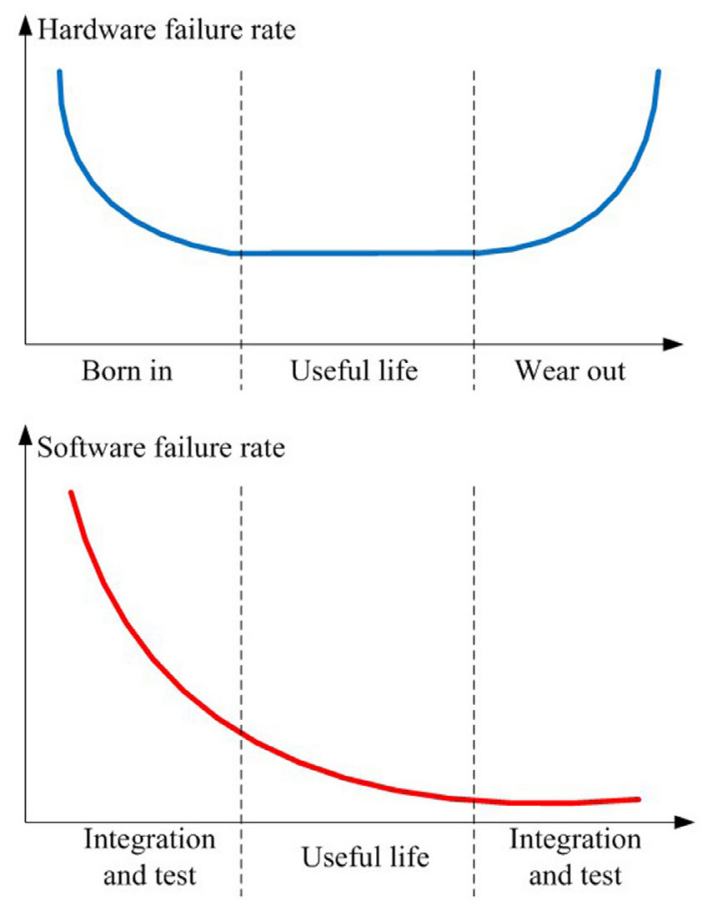

Figure 4. Technical system's software and hardware reliability curves as per (Vijayalakshmi, 2014)

The number of failures decreases over time because the components where failure occurred have been identified and replaced by new components or their operation has been stabilized. For a certain period of time, the system is in stable state in which there is a minimum number of failures. In time, in the course of usage, the system components wear out and age and the rate of their failures/malfunctions increases.

If the technical system software reliability curve is analyzed, it can be seen that the rate of failures/errors is gratest at the moment of software integration and during initial tests. After the initial software testing, the observed errors are eliminated, and the procedure of the system improvement is continually reiterated with the assumtion that new errors do not occur in neither of the new cycles. At one moment of the system operation, failure degree reaches the lowest level. Unlike the hard- 


\begin{tabular}{|c|c|c|c|c|c|c|c|}
\hline \multicolumn{8}{|c|}{ HARDWARE } \\
\hline No. & Failure mode & $\begin{array}{l}\text { Functions / } \\
\text { Conditions }\end{array}$ & Failure causes & Failure effests & $\begin{array}{l}\text { Effects on } \\
\text { systens }\end{array}$ & $\begin{array}{l}\text { Process } \\
\text { control }\end{array}$ & $\begin{array}{l}\text { Recommended ac- } \\
\text { tions }\end{array}$ \\
\hline 1 & Keyboard failure & $\begin{array}{l}\text { Allows the user } \\
\text { to perform/ex- } \\
\text { ecute operations } \\
\text { on the mobile } \\
\text { phone }\end{array}$ & $\begin{array}{l}\text { Due to acciden- } \\
\text { tal falls, water } \\
\text { infiltration, } \\
\text { wrong utilization } \\
\text { by user, manu- } \\
\text { facturing error. }\end{array}$ & $\begin{array}{l}\text { Incapability to } \\
\text { execute actions }\end{array}$ & $\begin{array}{l}\text { No operation or } \\
\text { wrong data }\end{array}$ & $\begin{array}{l}\text { Tests; } \\
\text { inspection }\end{array}$ & $\begin{array}{l}\text { Change keyboard } \\
\text { material to a stronger } \\
\text { and reliable one; more } \\
\text { supervision }\end{array}$ \\
\hline 2 & Battery failure & $\begin{array}{l}\text { Provides energy } \\
\text { and sustainabil- } \\
\text { ity to the mobile } \\
\text { phone }\end{array}$ & $\begin{array}{l}\text { Due to inap- } \\
\text { propriate use } \\
\text { of battery; } \\
\text { inappropriate } \\
\text { type of battery; } \\
\text { overcharging } \\
\text { and aging; neg- } \\
\text { ligent utilization } \\
\text { by custumer }\end{array}$ & $\begin{array}{l}\text { No power on; } \\
\text { dissatisfaction } \\
\text { by the costumer; } \\
\text { risk of explosion; } \\
\text { need frequent } \\
\text { charging }\end{array}$ & $\begin{array}{l}\text { Constant shut } \\
\text { down; durability } \\
\text { of the battery too } \\
\text { insufficient for a } \\
\text { correct utiliza- } \\
\text { tion of mobile } \\
\text { phone }\end{array}$ & $\begin{array}{l}\text { Tests; } \\
\text { inspection }\end{array}$ & $\begin{array}{l}\text { Utilization of appro- } \\
\text { priate batteries; more } \\
\text { supervision }\end{array}$ \\
\hline 3 & $\begin{array}{l}\text { Mobile phone } \\
\text { shell failure }\end{array}$ & $\begin{array}{l}\text { Covering and } \\
\text { protecting the } \\
\text { internal compo- } \\
\text { nents }\end{array}$ & $\begin{array}{l}\text { Low material } \\
\text { quality; manu- } \\
\text { facturing desigh } \\
\text { errors }\end{array}$ & $\begin{array}{l}\text { Unappeal- } \\
\text { ing esthetics; } \\
\text { uncomfortable } \\
\text { utilization by } \\
\text { users; low resist- } \\
\text { ance to physical } \\
\text { contact }\end{array}$ & $\begin{array}{l}\text { Broken } \\
\text { frequency; } \\
\text { more external } \\
\text { scratches; less } \\
\text { anti stress factor, } \\
\text { low withstand- } \\
\text { ing power in falls } \\
\text { and less water } \\
\text { resistant }\end{array}$ & $\begin{array}{l}\text { Tests; } \\
\text { inspection }\end{array}$ & $\begin{array}{l}\text { Selection of appropri- } \\
\text { ate material for the } \\
\text { shell; more supervi- } \\
\text { sion }\end{array}$ \\
\hline 4 & $\begin{array}{l}\text { Mobile phone } \\
\text { screen/display } \\
\text { failure }\end{array}$ & $\begin{array}{l}\text { To interact with } \\
\text { the user; protec- } \\
\text { tion for internal } \\
\text { display }\end{array}$ & $\begin{array}{l}\text { Low material } \\
\text { quality and man- } \\
\text { ufacturer error; } \\
\text { wrong utilization } \\
\text { by user }\end{array}$ & $\begin{array}{l}\text { Incapability to } \\
\text { interact with } \\
\text { other function }\end{array}$ & $\begin{array}{l}\text { Incapability to } \\
\text { interact with } \\
\text { other functions }\end{array}$ & $\begin{array}{l}\text { Tests; } \\
\text { inspection }\end{array}$ & $\begin{array}{l}\text { Black screen; color } \\
\text { change; low image } \\
\text { quality; external } \\
\text { scratches; poor resolu- } \\
\text { tion and low thermal } \\
\text { withstanding }\end{array}$ \\
\hline 5 & $\begin{array}{l}\text { Power supply } \\
\text { unit failure }\end{array}$ & $\begin{array}{l}\text { To supply DC } \\
\text { power to all } \\
\text { components }\end{array}$ & $\begin{array}{l}\text { Manufacturing } \\
\text { errors }\end{array}$ & $\begin{array}{l}\text { Incapable of sup- } \\
\text { ply of electricity } \\
\text { to the internal } \\
\text { circuits }\end{array}$ & $\begin{array}{l}\text { Low resolution } \\
\text { image; short } \\
\text { circuit and poor } \\
\text { international } \\
\text { connectivity }\end{array}$ & $\begin{array}{l}\text { Tests; } \\
\text { inspection }\end{array}$ & $\begin{array}{l}\text { More reliable } \\
\text { materials; careful } \\
\text { manufacturing; more } \\
\text { supervision }\end{array}$ \\
\hline \multicolumn{8}{|c|}{ SOFTWARE } \\
\hline 6 & Freeze & $\begin{array}{l}\text { Sudden software } \\
\text { hanging }\end{array}$ & $\begin{array}{l}\text { Due to more } \\
\text { operation; poor } \\
\text { memory capac- } \\
\text { ity; less software } \\
\text { quality }\end{array}$ & $\begin{array}{l}\text { Malfunction and } \\
\text { hanging }\end{array}$ & $\begin{array}{l}\text { Not able to oper- } \\
\text { ate the required } \\
\text { function; im- } \\
\text { proper output }\end{array}$ & $\begin{array}{l}\text { Tests; } \\
\text { inspection }\end{array}$ & $\begin{array}{l}\text { Selection of ap- } \\
\text { propriate and reliable } \\
\text { software; more super- } \\
\text { vision }\end{array}$ \\
\hline 7 & Shelf-shut down & $\begin{array}{l}\text { Sudden shut } \\
\text { down accidently }\end{array}$ & $\begin{array}{l}\text { Poor battery or } \\
\text { software prob- } \\
\text { lem or memory } \\
\text { access violation } \\
\text { error }\end{array}$ & $\begin{array}{l}\text { Create problems } \\
\text { for various } \\
\text { hardware and } \\
\text { malfunctions of } \\
\text { software }\end{array}$ & $\begin{array}{l}\text { Frequent shut } \\
\text { down; improper } \\
\text { output }\end{array}$ & $\begin{array}{l}\text { Tests; } \\
\text { inspection }\end{array}$ & $\begin{array}{l}\text { Utilization of appro- } \\
\text { priate batteries; more } \\
\text { supervision }\end{array}$ \\
\hline 8 & $\begin{array}{l}\text { Unstable be- } \\
\text { havior }\end{array}$ & $\begin{array}{l}\text { There is no } \\
\text { stable output in } \\
\text { apps }\end{array}$ & $\begin{array}{l}\text { Due to operating } \\
\text { system or poor } \\
\text { apps software } \\
\text { quality }\end{array}$ & $\begin{array}{l}\text { Malfunction } \\
\text { or hanging of } \\
\text { system }\end{array}$ & Improper output & $\begin{array}{l}\text { Tests; } \\
\text { inspection }\end{array}$ & $\begin{array}{l}\text { Selection of ap- } \\
\text { propriate and reliable } \\
\text { software; more super- } \\
\text { vision }\end{array}$ \\
\hline 9 & Output failure & $\begin{array}{l}\text { No output for } \\
\text { the given input }\end{array}$ & $\begin{array}{l}\text { Input hardware } \\
\text { problem (touch } \\
\text { screen, button, } \\
\text { etc.); software } \\
\text { problem }\end{array}$ & Malfunction & Improper output & $\begin{array}{l}\text { Tests; } \\
\text { inspection }\end{array}$ & $\begin{array}{l}\text { Careful manufactur- } \\
\text { ing; more supervision }\end{array}$ \\
\hline 10 & $\begin{array}{l}\text { Failure data } \\
\text { logger }\end{array}$ & $\begin{array}{l}\text { Error output for } \\
\text { the given input }\end{array}$ & $\begin{array}{l}\text { Internal hard- } \\
\text { ware problem } \\
\text { or software } \\
\text { problem }\end{array}$ & No data & $\begin{array}{l}\text { No output; im- } \\
\text { proper output }\end{array}$ & $\begin{array}{l}\text { Tests; } \\
\text { inspection }\end{array}$ & $\begin{array}{l}\text { Careful manufactur- } \\
\text { ing ;more supervision }\end{array}$ \\
\hline
\end{tabular}

Table 4. Application of FMEA on hardware and software components of mobile phones 
ware system portion, the software cannot be physically worn. Nonetheless, it becomes obsolete after some time and useless due to arrival of a new software.

\section{MOBILE PHONE ANALYSIS BY USING FMEA METHOD}

The objective of conducted research is to perform the analyses of various failure modes and effects for both hardware and software of the mobile phone.

A standardized form used in practice in the course of conducting FMEA analysis is not appropriate for this paper for technical reasons. The contents of the FMEA form is divided into two parts and represented in Table 4 and Table 5.

For each of the defined failure modes, the RPN value is calculated on the basis of which assessment is made of failure criticality degree. On the basis of the obtained RPN value, ranking of the defined failure modes is made, as depicted in Table 5.

By applying the brainstorming technique, ten most frequent mobile phone failure modes have been determined. The analysis conducted for five most frequent hardware failure modes and five most frequent software failure modes. Values of three parameters have been estimated: failure severity, failure occurrence probability and failure detection measures. The causes of failure occurrence for each failure mode and failure effect have been defined in the sense of their influence on the component and on the whole system. For each of the defined failures, proposal of actions has been given aimed at eliminating the causes of failure occurrence.

Failure severity represents maybe the most influential parameter on certain RPN values and it is formed on the basis of the data on injury level, property damage and system damage. Failure severity assessment has been made by way of the data stated in Table 1 . The failure occurrence probability has been determined by way of the classification given in Table 2. Detection represents the probability that the failure will be identified even before it affects the system operation. The values for failure severity, probability and detection have been ranked from 1 to 10,10 being the rate for the most hazardous effect. On the basis of estimated values of these three parameters, the RPN has been calculated and the risks have been ranked.

\begin{tabular}{cccccc}
\hline $\begin{array}{c}\text { Failure } \\
\text { modes }\end{array}$ & Sev. & Occ. & Det. & RPN & $\begin{array}{c}\text { Rank } \\
\text { Number }\end{array}$ \\
\hline 1 & 8 & 5 & 4 & 160 & 4 \\
\hline 2 & 8 & 7 & 4 & 224 & 2 \\
\hline 3 & 4 & 8 & 8 & 256 & 1 \\
\hline 4 & 8 & 6 & 2 & 96 & 5 \\
\hline 5 & 8 & 5 & 5 & 200 & 3 \\
\hline 6 & 7 & 7 & 6 & 294 & 2 \\
\hline 7 & 8 & 7 & 6 & 336 & 1 \\
\hline 8 & 8 & 4 & 3 & 96 & 5 \\
\hline 9 & 9 & 5 & 3 & 135 & 3 \\
\hline 10 & 9 & 3 & 4 & 108 & 4 \\
\hline
\end{tabular}

Table 5. Calculation of RPN for hardware/software components

\section{DISCUSSION OF OBTAINED RESULTS}

In the conducted FMEA analysis, from the results depicted in Table V, only the "major" failures in the system have been considered. Minor failures that may occur were not taken into consideration in the course of the FMEA analysis. After ranking the risks, the obtained results show that malfunction in the mobile phone housing has got the highest RPN value. Therefore, in case of problems with the mobile phone housing, the risk is increased for the mobile phone user during use of the mobile phone. If the whole system is observed from the software point of view, the highest RPN value is attributed to the failure mode of self-switching off of the device. Such failure mode is very risky as it causes loss of data and/or malfunction of the mobile phone operating system. Regarding smart phones, special attention should be paid to proper and safe access to the phone memory. The results of the analysis have shown that errors/failures in mobile phone hardware occur much more frequently than in software.

If the obtained results are compared with the results of the Vijayalakshmi (2014) and Marques (2010) analyses results, it is evident that the RPN is not identical even for the same failure modes. However, the sequence according to which the failure modes have been ranked is identical. That means that mobile phone housing malfunction, as well as self-switching off of the device are treated as the highest priority risks. 
But nevertheless, are the obtained results completely true? If solely the failure criticality degree values are considered, it is then obvious that the malfunction occurring in the mobile phone housing has got the highest RPN value (256). In that case, the value of failure effect severity is very low (4), on the basis of which it can be concluded that mobile phone housing failure certainly is not the failure which deserves the highest priority. On the other hand, there are components of the system for which in the conducted analysis a high RPN value has not been obtained, but they should certainly be treated as high priority failures because the values of the failure effect severity and/or failure occurrence probability are very high.

The obtained results point to the fact that the procedure of applying FMEA is not simple and clear-cut. For the purpose of obtaining the final results on risk priorities, it is desirable to obtain more additional data on the system, or to apply some additional analysis measure. As by the tabular arrangement of data on system failures are obtained applying the FMEA method, there is the possibility of graphical linking of the data, i.e. of the failure tree construction. In that respect, good results are obtained by joint application of the FMEA and FTA methods, since these two methods are complementary. Proper application of the FMEA method implies the failure mode independence. This fact makes the analysis more difficult, e.g. in cases when mutual hardware and software effects occur in the system, i.e. in case when the assumption of failure mode independence is not valid. When such problems exist, the use of the FTA method is recommended.

\section{FINAL CONSIDERATIONS}

Mobile phones offer a wide scope of possibilities to their users. However, failures that may occur in the course of mobile phone use can significantly jeopardize operation of the device which requires additional costs for servicing of the equipment. Mobile phone malfunctioning can also endanger health and safety of the users. The FMEA is very often used in designing technical systems. FMEA results can prevent reoccurrence of the problems that existed in the system. The analysis of the obtained results provides good guidelines for improving the entire technical system and contributes to accomplishment of the radio equipment safety concept.

\section{REFERENCES}

Bašić, A., Popović, P. (2014). Risk assessment procedures for products which do not fulfill the essential requirements of RTTE directive. In: SINTEZA (907913). Belgrade: Singidunum University

Bašić, A., Popović, P. (2015). Risk assessment methodology in use of mobile phones. In: SINTEZA (232237). Belgrade: Singidunum University

Đapić, M., Popović, P., Lukić, Lj., and Mitrović, R. (2012). Risk Assessment Concept in the New Approach Directives and its integration in the Enterprise Risk Management (ERM). Industrija. Volume 40, 3-38.

Marques, L.M.C. (2010). FMEA- Mobile phone. University of Ljubljana. Retrieved February 20, 2016, from http://lrss.fri.uni-lj.si/sl/teaching/zzrs/lectures/2010_Marques.pdf

Square Trade Research brief .(2010). Smart phone reliability: Apple iphones with fewest and major Android manufacturers not far behind. Retrieved February 25, 2016, from http://www.wired.com/ images_blogs/gadgetlab/2010/11/SquareTrade_ Cell_Phone_Comparison_Study.pdf

Vijayalakshmi, K. (2014). Analysis of Android OS Smart Phones Using Failure Mode and Effect Analysis. International Journal of Latest Trends in Engineering and Technology, 4 (4), 11-18. 